\title{
Management of Learning Companies: Problems and Prospects
}

\author{
Khanif Sharifzyanovich Mullakhmetov ${ }^{1}$, Ruslan Duferovich Sadriev², Elvira Ructemovna Gafiyatullina ${ }^{3}$ \\ ${ }^{I}$ Candidate of economic sciences, Associate Professor of the Department of Production Management, Division of Economics, \\ Higher School of Economics and Law, Naberezhnye Chelny Institute of KFU (Kazan Federal University), Russia. \\ Idscopus: 56436785600, ORCID ID: 0000-0002-4029-2154, \\ ${ }^{2}$ Candidate of economic sciences, Associate Professor of the Department of Production Management, Division of Economics, \\ Higher School of Economics and Law, Naberezhnye Chelny Institute of KFU (Kazan Federal University), Russia.
}

Idscopus: 57192306139, ORCIDID: 0000-0003-3683-9548,

${ }^{3}$ Candidate for a master's degree, Department of Production Management, Division of Economics, Higher School of Economics and Law, Naberezhnye Chelny Institute of Kazan Federal University, Russia.

ORCID ID: 0000-0003-3369-0477,

\begin{abstract}
In the context of constant changes in all spheres of social life, one of the approaches to ensuring effective management and strategic competitiveness is the formation of learning companies. The paper discusses a number of aspects of individual and organizational learning and proposes the authors' vision of the main characteristics of the learning company management, which can be considered as requirements for the management of learning companies in the study of management systems. The research examined three approaches to identifying errors and increasing the effectiveness of learning highlighted in the scientific literature on management. The relevance of the study is due to the fact that it is more and more difficult for top managers of companies and their owners to ensure effective activities of companies in their short-term prospects, and also their longterm strategic competitiveness in the context of a constantly changing business environment, growing uncertainty of management results, qualitative changes in the characteristics of human capital, changes in society and other global trends characteristic of the 21 st century. 10 main characteristics of management that promote learning were formulated on the basis of the analysis of the available open sources. They are also the basis of the requirements for the corporate culture of self-learning organizations.
\end{abstract}

Keywords: Intellectual Models, Learning Culture, Factors Of Adaptation And Transformation Of Management, Human Capital, Managerial Potential, Characteristics Of Learning Company Management

\section{INTRODUCTION}

The quintessence of the entire management activity is the development, adoption and implementation of management decisions: managers must be able to make high-quality management decisions that are adequate to the problem under consideration and to ensure the effective implementation of the decisions made. These actions constitute the basic competence of managers [1]. The information management system is of essential importance in the system of procedures for managerial decisions; it largely determines both the quality of managerial decisions and the quality of their implementation [2]. When making decisions, not explicitly formulated and formalized rules, procedures and norms operating in the organization (i.e. not the tools and methodology of formal management) become important, first of all, but implied rules, taking into account the characteristics of the modern business environment (multifactorial nature, variability, uncertainty). They are formulated by managers and are individually based on the available and predictive characteristics of the environment for each managerial situation, and also based on intuition and common sense, experience and judgments. This situation requires not only a revision of the ratio between formal and informal management, but also introducing qualitatively new requirements for managerial potential and human capital, and makes individual and organizational learning in companies practically important. Creating a culture of learning and culture of learning organizations themselves is becoming a prerequisite for their survival and long-term strategic competitiveness.

\section{METHODS}

Daniel G. Kim, a co-founder of the MIT Center for Organizational Learning, simplifies the image of a learning process as a constantly rotating wheel. In the first half of the cycle, we acquire skills by testing our concepts and observing what happens by experience; then, reflecting our observations and forming concepts, we gain knowledge. Skills and knowledge form thinking stereotypes, which are often referred to as intellectual models. "...Intellectual models represent our individual vision of the world, including explicit and tacit, unspoken knowledge. Intellectual models create a context in which a person perceives and interprets specific situations." [3]

Stereotypes of thinking, or intellectual models, are strictly individual, which determines the different reactions of people to the same situations. These circumstances complicate not only communication processes and they are a source of uncertainty in management, but they also create a number of problems in the learning process. 
There are three approaches to identifying errors and increasing the effectiveness of learning in scientific and popular science literature.

The first approach focuses on smart models and assumes that latent smart models are the cause of failures in organizational and individual learning. The most famous proponent of this approach is Christopher Argyris, a professor at Harvard University.

The second approach considers cause-effect intellectual models, when the causes and effects in the events occurring are defined incorrectly. This approach is most closely associated with the work of Peter Senge and Jay W. Forrester.

A third approach with broader reach of aspects focuses on the culture of organizations and the conditions necessary for effective learning in work teams. This approach is most vividly cultivated in the works of Edgar Shane, a professor at the Sloan School of Management at the Massachusetts Institute of Technology, who is considered the chief architect of learning culture.

Let's take a closer look at the third approach, which can be called as creating a learning culture. Edgar Shane defines organizational culture "as the accumulation of prior learning from past success" [4], thereby emphasizing the relationship between learning and culture. Culture is seen by him as "a matrix of assumptions... which are invented, discovered and developed by a particular group... in the process of learning to solve their problems... and which work well enough to be valid. Therefore, they... should be taught to new members of the organization as the correct way of perception, thinking and the correct attitude to these problems." [5]

\section{RESULTS AND DISCUSSION}

Peter Senge and his coauthors in their book "Dance of Change: New Challenges for Self-Learning Organizations" actively promoted the idea that the survival and competitiveness of modern companies is not determined by tangible assets, but by the ability of human capital to change and reform (initiate, implement, perceive and use changes) existing concepts and control systems. [6]

Scientists from Kazan (Volga Region) Federal University, I.R. Gafurov, M.R. Safiullin, A.R. Safiullin emphasize that in the conditions of the "new economy" "... a qualitative change in the structure of demand, ... acceleration of technological changes, and expansion of the information space lead to the limitation of price factors for the growth of competitiveness and... strategic competitive advantage is formed at the level of business processes, the effective functioning of which depends on the quality of management". [7]

To implement effective management in modern companies, flexible management systems are required, the quality of which is determined by managerial potential, characteristics of human capital, the ability of managers to change and learn [8], [9]. Itzhak Adizes believes that "the main task of managers today is change management; in the future the importance of this work will only increase." [10] The nature and mechanism of the influence of changes in the key environmental factors for the organization on the management system of companies were considered by us in [11], and the main groups of factors of adaptation and transformation of management and its individual subsystems in [12].

A strong corporate culture, which, among other things, has a normative meaning as a way of "soft" regulation of the actions and behaviour of personnel in the general trend of humanization of management coordinated with the strategy of the company's functioning and development, becomes a powerful mechanism for increasing management efficiency. [13], [14], [15].

\section{SUMMARY}

Based on the results of the analysis of available open sources, we will formulate the main characteristics of management that promotes learning. They are also the basis of the requirements for the corporate culture of self-learning organizations.

1. Striving to balance the interests of all participants in corporate relations: owners, managers, employees, consumers and suppliers, state and local authorities, and civil communities. The implementation of production plans, an emphasis on quantitative indicators, the priority of only the economic effect in making management decisions is gradually inferior to the systemic approach in assessing the effectiveness of the social effect of management decisions, taking into account socio-cultural factors.

2. Recognition and implementation of the concept that management, as an area of human relationships, can be effective in recognizing the dominant role of people. A technocratic approach based on systems and technologies without taking into account the characteristics of human capital does not correspond to the realities of the economy.

3. Democratic management style, partnership relations between managers and subordinates; moral and psychological climate providing confidence in the future in their team to every employee.

4. A systematic approach to solving problems recognizing the interconnection of all aspects of the organization's life. Refusal from the practice of permanently solving production and economic problems at the expense of social resources

5. Efficient continuous and open information flows along vertical (forward and backward) and horizontal links in the management system. Power and authority are not formed by the position and not the possession (concealment or distortion) of information, but the opinion of colleagues working side by side, based on the contribution of each to the common cause.

6. Emphasis on group work, building teams with their key competencies. Competition between individuals gives way to the ability to interact in groups.

7. Transfer of emphasis from administration and control to the creation of an environment conducive and initiating individual and group learning; resource provision of learning. 
8. Transition from traditional management systems to fractal management with the minimum necessary framework rules.

9. Formation and development of "soft" management forms based on socio-cultural, moral and ethical tools, taking into account national and geographical factors.

10. Transition from long-term plans and forecasts to new forms of organizational structures that provide flexibility of management systems at the level necessary to establish and maintain an effective balance of stability and flexibility.

\section{CONCLUSIONS}

The main problem of the 21 st century, which worries the top managers of companies and their owners, is caused by constant changes in the business environment, the growing uncertainty of the results of management activities, qualitative changes in the characteristics of human capital, changes in society and other global trends. It can be summarized as: "How to ensure effective operation of companies today and their long-term strategic competitiveness in the face of constant changes in all spheres of society? [16]. Many experts suggest providing effective individual and organizational learning to solve the problem, which makes certain demands on the management of companies. At the same time, the general trend aimed at the humanization of management requires an increase in the role of "soft" forms (methods and technologies) based on social, moral, psychological, ethical tools, and organizational culture. [17]

\section{ACKNOWLEDGEMENTS}

The work is performed according to the Russian Government Program of Competitive Growth of Kazan Federal University.

\section{REFERENCES}

[1] Mullakhmetov K. Control in the system of managerial decisions procedures: A conceptual view. Problems and Perspectives in Management. 2016 Jan 1;14(3):64-76.

[2] Mullakhmetov KS, Sadriev RD, Bikulov RA, Khairullin IG, Akhmetshin EM. Information assurance of the procedure of development of management decision-making. InProceedings of the 32nd International Business Information Management Association Conference, IBIMA 2018-Vision 2020: Sustainable Economic Development and Application of Innovation Management from Regional expansion to Global Growth 2018 (pp. 6433-6442).

[3] Kim DH. The Link between Individual and Organizational Learning. Sloan Management Review, 1993: p.39.

[4] Schein EH. How can organizations learn faster?: the problem of entering the Green Room. Sloan Management Review. 1995: p.87.
[5] Schein E. Organizational Culture. American Psychologist. 1990, February, p.111.

[6] Senge P. Dance of Change: New Problems of SelfLearning Organizations. M.: Olimp-Biznes. 2004:43345 .

[7] Gafurov IR, Safiullin MR, Safiullin AR. The analysis of competitiveness structural gaps in the production of petrochemical cluster in the Republic of Tatarstan. Kazan: Kazan University. 2012:286.

[8] Mullakhmetov KS, Sadriev RD, Krotkova EV, Sharafutdinov RI. Culture as a factor of influence on the management potential of modern organizations. Helix. 2018 Jan 1;8(1):28.

[9] Mullakhmetov KS, Sadriev RD, Gabaidullina LA, Akhmetshin EM. Influence of human capital characteristics on transformation of management and control in the management of social and economic systems. InInnovation Management and Education Excellence through Vision 20202018 (pp. 3562-3572).

[10] Adizes I. Theory and practice of management transformation before new challenges-Russia has to catch up. Harvard Business Review-Russia. 2017:6-10.

[11] Mullakhmetov KhSh. Problems of management and control in conditions of uncertainty. Management in Russia and abroad. 2015: 25-34.

[12] Mullakhmetov KS. Technological Factors and Management Transformation in Social and Economic Systems. European Research Studies Journal. 2018; 21(3): 230-241.

[13] Thompson AA, Strickland III, AI. (). Strategic Management: Concepts and Cases (12th ed.). Moscow: Williams publishing house. 2013:p.928.

[14] Mullakhmetov KS, Sadriev RD, Bikulov RA, Akhmetshin EM. Sociocultural factors of transforming administration and control in the management of economic and social systems under modern conditions. InInnovation Management and Education Excellence through Vision 20202018 (pp. 3573-3581).

[15] Sadriev RD, Mullakhmetov KS, Krotkova EV, Gabaidullina LA. Introduction of lean production at Russian enterprises: Perspectives and problems. International Journal of Economics and Financial Issues. 2016;6(8S).

[16] Lindgren M, Bandkhold H. Scenario planning. Communication between the future and strategy. Moscow: Olympe-business. 2009;256 p. (in Russian)

[17] Mullakhmetov KS. Influence of evolution of management on the organization of control. 4th International scientific conference "European Applied Sciences: Modern approaches in scientific researches": Pages of the 4th International scientific conference, 2(Studgard, Germany). 2013b;176-182. 


\section{Brief biographies of authors}

Khanif Mullakhmetov, Candidate of Economic Sciences, Associate Professor of the Department of Management in the branch of the Kazan (Volga Region) Federal University (Naberezhnye Chelny, Republic of Tatarstan). Yt was born in 1956 in the Aktanysh region of the TatASSR. He has experience of work in the top management of large Russian and joint companies in the engineering, construction industry and construction, where he was engaged in the development and implementation of corporate control and internal control systems. His practical activities have been appreciated by government awards and titles "Honoured Economist of the Republic of Tatarstan", "Honorary Mechanical Engineer of the Russian Federation", and others. Currently, he is a practicing independent consultant and expert on management and control problems, researching the problems and prospects of adaptation and transformation of management and its basic subsystems to the conditions of the "new economy". Research interests: management, managerial control, efficiency of management and control systems.

Ruslan Duferovich Sadriev was born in 1970 in the city of Dushanbe, Tajik SSR. In 1993, after successfully defending his diploma project at the Kama Polytechnic Institute (KAMPI), he received the qualifications of a mechanical engineer and was admitted to KamAZ, where he worked as a process engineer, site manager, head of the technological bureau, and design engineer. As a design engineer and as the main developer, he independently led projects; he also was the head of project teams. In 2004 he graduated from the correspondence faculty of KPI and received the qualification of an economist-manager; since 2005 he worked at the Academy of Engineering and Economics (INEKA) as an assistant, senior lecturer, assistant professor in the departments of Management and Marketing, Logistics and Management; from 2012 to the present day he has been working as an associate professor at the Department of Industrial Management at the Naberezhnye Chelny Institute of KFU. In 2010 he defended his thesis at the State University of Management (Moscow) in the specialty "Economics and National Economy Management"; in 2016 he received the title of Associate Professor in the specialty "Economics and National Economy Management". From 2016 to 2017, he participated in the research work "Corporate culture as a management and control tool in a management system working in a competitive environment (by the example of the petrochemical industry of the Republic of Tatarstan)" of the BP program. He is an author of over 50 scientific works, including a textbook with the stamp of the UMO VO (educational and methodological association of higher education) on marketing, management, and lean management.

Elvira Rustemovna Gafiyatullina was born on October 4, 1996. In 2014 she graduated from the technological lyceum No. 35 in Nizhnekamsk; in 2018 she graduated with honours from KFU (branch in Naberezhnye Chelny) with a degree in economics of enterprises and organizations with a bachelor's degree in economics. In the same year, she continued her studies in the magistracy of KFU (Naberezhnye Chelny) with a degree in innovation management. Since 2018, she has been working at KAMAZ PTC in the Internal Audit Service as a specialist. Her interests include creating illustrations using computer programs, reading fiction and scientific literature. For today, she has written three scientific papers. 